\title{
Impacts of the creation, expansion and management of English wetlands on mosquito presence and abundance - developing strategies for future disease mitigation
}

\author{
Jolyon M Medlock ${ }^{*}$ and Alexander GC Vaux
}

\begin{abstract}
The incidence of mosquito-borne diseases is increasing in Europe, partly due to the incursion of a number of invasive species known to be vectors of dengue and chikungunya viruses, but also due to the involvement of native species in the transmission of West Nile virus and malaria. For some of these pathogens, there is a risk of the re-emergence of vector-borne diseases that were once widespread in Europe, but declined partly due to large-scale land-drainage projects. Some mosquito species exploit container habitats as breeding sites in urban areas; an adaptation to human-made micro-habitats resulting from increased urbanisation. However, many species thrive in natural wetland ecosystems. Owing to the impacts of climate change there is an urgent need for environmental adaptation, such as the creation of new wetlands to mitigate coastal and inland flooding. In some cases, these initiatives can be coupled with environmental change strategies to protect a range of endangered flora and fauna species by enhancing and extending wetland landscapes, which may by driven by European legislation, particularly in urban areas. This paper reviews field studies conducted in England to assess the impact of newly created wetlands on mosquito colonisation in a) coastal, b) urban and c) arable reversion habitats. It also considers the impact of wetland management on mosquito populations and explores the implications of various water and vegetation management options on the range of British mosquito species. Understanding the impact of wetland creation and management strategies on mosquito prevalence and the potential risk of increasing the levels of nuisance or disease vector species will be crucial in informing health and well-being risk assessments, guiding targeted control, and anticipating the social effects of extreme weather and climate change. Although new wetlands will certainly extend aquatic habitats for mosquitoes, not all species will become a major nuisance or a vector concern as a result. Understanding how the design and management of wetlands might exacerbate mosquito densities is crucial if we are to manage nuisance mosquitoes and control vector species in the event of a disease outbreak. This entomological evidence-base will ensure that control strategies achieve optimal efficacy at minimal cost.
\end{abstract}

Keywords: Mosquito, Wetland, UK, Ecology, Climate change, Arbovirus, Aedes

\section{Introduction}

Aquatic insects such as mosquitoes are acutely responsive to changes in temperature and rainfall. The rate of development of all insects is directly proportionate to temperature, and in the case of mosquitoes this governs the rate of immature development, blood digestion, and egg production, as well as incidental issues such as the

* Correspondence: jolyon.medlock@phe.gov.uk

Medical Entomology group, Public Health England, Porton Down, Salisbury, Wiltshire SP4 OJG, UK rate of pathogen development within the mosquito. However, as an obligate aquatic insect, the degree of water availability has profound implications for the survival and abundance of immature mosquitoes. This is exemplified by the fact that the melting of winter snows in the Arctic can lead to the highest global abundances of mosquitoes, despite the cooler spring temperatures. In addition to the availability of water, the permanent/ transient nature of water bodies impacts on the mosquito's competitors and predators and hence any weather-

\section{Biomed Central}


driven or human-driven processes that affect the presence and distribution of aquatic habitats (including heavy rainfall or wetland management) will impact, to varying degrees, mosquito diversity and density $[1,2]$.

Excessive rainfall and subsequent flooding have significant effects on the available mosquito habitat. However, this is not always a positive impact on mosquito density, as excessive flooding can denude aquatic habitats of mosquitoes through flushing [3,4]. Similarly, artificial storage of rain or river water in wetlands, coastal flooding and sea incursions following high spring tides may also create mosquito habitats, independent of rainfall [5]. Similarly, the irrigation of arable systems in semiarid regions can artificially create mosquito habitats irrespective of weather events [6,7].

The effects of these processes on mosquito abundance and diversity can be demonstrated by various field-based studies on mosquitoes in England. Firstly, however, it is important to understand the drivers of flooding and the strategies employed during wetland and floodwater management.

\section{Drivers for wetland creation and expansion}

One of the main challenges to adapting to climate change has been the development of national and regional strategies to mitigate coastal and inland flooding through the provision of new wetlands $[8,9]$. In addition, in an attempt to increase the amount of suitable habitat available for wildlife to cope with changes in climate (and extreme weather events), new wetlands are being created and failing wetlands are being restored through careful wetland management. In England, for example, Wetland Vision, sponsored by the UK Department of Environment, Food and Rural Affairs, Natural England, the Environment Agency and wildlife groups, such as the county-based Wildlife Trusts, have developed a clear vision to restore existing wetlands, double the number of ponds, and increase the area of coastal and grazing marsh by 2050 [9]. This mimics a number of similar initiatives across Europe.

Many of these strategies involve recreating wetland landscapes in areas where wetlands had previously dominated. For example, plans to create new coastal habitats in eastern and southern England aim to mitigate rises in sea levels, or offset loss of European protected saltmarsh and mudflat habitat in areas where coastal wetlands have been drained for agriculture [10]. Inland, in urban areas, new wetlands are being created as part of ecological mitigation for new housing developments, with a strong driver to provide mitigation habitat for European and UK protected species such as the Great Crested Newt and the Water Vole [11].

Some of the largest landscape-scale plans for wetland creation include projects such as the Great Fen project
[12] and the Wicken Fen vision [13] in Cambridgeshire. The intention is to extend the existing highly biodiverse wetlands to increase the wildlife value of existing nature reserves and minimise their fragmentation, thereby restoring a lost wetland landscape, as well as increasing the available habitat for birds, rare plants and invertebrates. However, they also act as a storage facility for floodwater, a common feature of the inland and coastal wetland creation schemes. Similar examples can be found across the UK, including on post-industrial sites, such as mining flashes and gravel pit extractions, as well as across parts of Europe, particularly in areas associated with river valleys prone to flooding.

In addition to the wildlife benefit, wetlands are also valuable habitats because they provide important social, economic, and ecological services, such as flood control, water quality improvement, carbon sequestration and pollutant removal [14]. Wetlands also have high aesthetic and recreational value, which makes wetland landscapes highly desirable for improving human well-being and in turn promote local rural economies through increasing tourism and development of new settlements.

\section{Changing mosquito-borne disease risk in Europe}

The main drawback associated with wetlands is the prospect of an increase in nuisance biting flies and the potential for mosquito-borne disease transmission. In recent decades, England has been free of the transmission of infectious pathogens by mosquitoes, although it is less than 100 years since malaria was endemic in coastal marsh and fenland areas of England [15]. Furthermore, since the serious emergence of West Nile virus in North America in 1999 a great deal of attention has focussed on the role of both native and non-native mosquito species in the transmission of diseases to humans in Europe [16]. In the last five years continental Europe has witnessed its own local and ongoing transmission of West Nile virus to humans across large areas of the Eastern and Central Mediterranean. In 2012 there were 937 WNV cases in 16 countries in Europe and North Africa, with a further 785 WNV cases in 15 countries in 2013 [17]. European mosquitoes have been responsible for the transmission of Plasmodium vivax malaria in Greece [18], the emergence of African flaviviruses, such as Usutu virus in central Europe [19], and the prospect of European transmission of Rift Valley fever virus by European mosquitoes remains a grave concern of EU agriculture bodies [20]. In addition, two other arboviruses transmitted by European mosquito species occur cyclically in Europe: Sindbis virus in Scandinavia [21] and Tahyna virus in the Dyje and Danube river areas [22]; both of which are causative agents of human disease. Furthermore, the recent appearance of non-native invasive mosquitoes (e.g. Aedes albopictus, Aedes aegypti, Aedes japonicus) 
and their involvement in European transmission of dengue virus and chikungunya virus has raised the prospect of mosquitoes as a cause of public health concern in Europe [23,24].

One of the challenges, therefore, for wetland managers, those involved with flood alleviation and entomologists involved with public health assessment, is ensuring that existing and new wetlands, as well as flooding events (and flood risk plans), do not cause concern for public health disease risk either now or in the future [2]. Across Europe there are notable examples of how natural and unnatural flooding exacerbates mosquito nuisance and mosquitoborne disease issues. Such examples include increases in the abundance of Aedes sticticus and Aedes vexans following flooding events in the valleys of the main European rivers, such as the Dyje, the Danube and the Rhine [22,25], as well as enormous mosquito densities associated with seasonal flooding in the Swedish wetlands [26,27]. Massive increases in the abundance of Aedes caspius are also reported each year in the Camargue wetland system of France [28] and in the rice fields of the Piedmont Region in Italy [7].

UK initiatives to adapt to climate change include a number of field-based investigations of the impacts of flood alleviation, wetland creation and wetland management in England $[2,5,29]$ and also in the Netherlands. The UK currently has 34 recorded species of mosquito, some of which have only been identified as new to the country in recent years [30-33]. A full list of British species and their favoured habitat are detailed in Table 1. Unlike the invasive Aedes species establishing in Europe, our endemic mosquito fauna exploit a range of habitats including permanent, temporary and container habitats, fresh or saline waters, flooded grassland or woodland habitats, tree-holes and underground sites. Some species show habitat specificity, whereas others are generalists. Some species require permanent aquatic habitats for survival, whereas others rely on a period of drying and can be pioneer species in new aquatic habitats. The impact of wetland creation, expansion and management will, therefore, impact each species in different ways. Here we discuss the impacts of three wetland initiatives in England in relation to future mosquito nuisance or disease vector implications.

\section{Coastal wetland creation - sea level rise management}

The winter of 2014 in southern England highlighted the risks posed to the British coastline by storm surges and high sea levels. In north-west Europe the prospect of sea-level rise, as well as the repeated incidence of coastal and estuarine flooding has led to the development of strategies to mitigate coastal flooding through the provision of new coastal habitat. This has prompted the implementation of managed realignment
(MRA) schemes along the coast, which essentially involve replacing artificial hard coastal defences with natural soft defences, such as coastal habitats [8]. MRA is the deliberate process of altering flood defences to allow flooding of a presently defended area. This practice is now considered to offer long-term sustainable management of coasts and estuaries for a variety of stakeholders. It can reduce the loss of intertidal habitat due to coastal squeeze (fixed defences at the high-water mark reduce the extent of intertidal areas) and offer potential new habitat creation and re-creation opportunities [8]. It is also being promoted to mitigate loss of European protected coastal habitats, with MRA being directly implemented as compensation sites for direct loss, usually through the Environmental Impact Assessment (EIA) process and/or as part of an Appropriate Assessment under EU legislation [10].

An MRA scheme may take many forms, including a) retreating to higher ground, i.e., where a line of defence is breached/removed, allowing inundation up to the higher ground, producing a new intertidal area, b) constructing a set-back line of defence, thus protecting property landward of the defence, or land at lower altitude to the defence, c) shortening the overall defence length to be maintained, thus reducing costs or d) inundation through sections of defence whereby the breach allows inundation of land behind it through a defined gap, or through pipes with tidal flaps to allow an intertidal area to develop behind the defence.

The flood management and environmental benefits of MRA are manifold [8]. These include a) reducing flood risk or reducing the long-term costs of flood defence by minimising costs of repairing defences, b) ensuring longterm sustainability of defences by increasing natural flood and storm-buffering capability, c) reducing the costs of maintaining defences, particularly where existing defences are not economically viable, d) assisting with managing the effects of sea level rise by reducing the height of sea/estuary levels, and e) mitigating the effects of previous reclamations and of climate change (i.e., sea level rise), and thus offsetting the impact of coastal squeeze. Most significantly, MRA lead to creation of intertidal habitat, usually mudflat and salt marsh areas with the associated benefits for wildlife and protected species, as well as improving recreational value.

Coastal aquatic habitats have long been known to provide suitable habitats for brackish-water mosquitoes and historically, coastal marshes were considered to support anopheline mosquito populations that were responsible for local malaria transmission [15]. Studies in England surveyed the eight largest managed realignment sites (in Essex and the Humber) for mosquito habitats [5]. The apparent absence of anopheline mosquitoes exploiting aquatic habitats at all of these sites suggests that the risk of malaria associated with MRA sites is currently 
Table 1 Summary of the impact of wetland creation and management on British mosquito species, with a summary of potential for mitigation and possible nuisance/vector concern

\begin{tabular}{|c|c|c|c|c|c|}
\hline Species & Status & Aquatic habitats & Impact of wetland creation & $\begin{array}{l}\text { Impact of wetland management } \\
\text { and possible mitigation }\end{array}$ & Human nuisance biting or vector concern \\
\hline $\begin{array}{l}\text { Anopheles algeriensis } \\
\text { Theobald }\end{array}$ & + & Fen, only in two local areas & None & N/A & $\begin{array}{l}\text { Not considered an important nuisance species } \\
\text { or potential disease vector }\end{array}$ \\
\hline $\begin{array}{l}\text { Anopheles atroparvus } \\
\text { van Thiel }\end{array}$ & ++ & Coastal, brackish & $\begin{array}{l}\text { No current evidence that newly } \\
\text { created coastal wetlands created } \\
\text { under managed re-alignment } \\
\text { will be colonised by this species. }\end{array}$ & N/A & $\begin{array}{l}\text { Causes nuisance in some coastal areas, however } \\
\text { is of less concern than Ae. detritus. Has the } \\
\text { potential to be a malaria vector, although the } \\
\text { risk of local transmission is considered very low. }\end{array}$ \\
\hline $\begin{array}{l}\text { Anopheles claviger } \\
\text { Meigen }\end{array}$ & +++ & $\begin{array}{l}\text { Primarily breeds in permanent } \\
\text { water such as ditches and } \\
\text { pools, and generally favours } \\
\text { heavily vegetated breeding sites. } \\
\text { It may also be found in transient } \\
\text { water habitats. }\end{array}$ & $\begin{array}{l}\text { New permanent wetlands with } \\
\text { ditches and pools will provide } \\
\text { new habitats for this ubiquitous } \\
\text { species. This species will also be } \\
\text { favoured where ditches are not } \\
\text { regularly brinked or slubbed, or } \\
\text { if they are left to dry out. }\end{array}$ & $\begin{array}{l}\text { This species can be kept in check } \\
\text { by maintaining healthy ditches } \\
\text { with plenty of predator competition, } \\
\text { regular brinking of ditches to keep } \\
\text { vegetation levels down and allow } \\
\text { sunlight through. }\end{array}$ & $\begin{array}{l}\text { This species is already widespread and is not } \\
\text { currently significantly associated with nuisance } \\
\text { biting. Although new wetlands might create } \\
\text { more habitat, there is no evidence to suggest } \\
\text { that it will become problematic. }\end{array}$ \\
\hline \multirow[t]{2}{*}{$\begin{array}{l}\text { Anopheles messeae } \\
\text { Falleroni/Anopheles } \\
\text { daciae Nicolescu }\end{array}$} & \multirow[t]{2}{*}{+++} & \multirow{2}{*}{$\begin{array}{l}\text { Breeds primarily in open sunlit } \\
\text { permanent freshwater pools } \\
\text { and ditches, including in } \\
\text { seasonally flooded grassland. }\end{array}$} & \multirow{2}{*}{$\begin{array}{l}\text { New permanent wetlands with } \\
\text { ditches and pools will provide } \\
\text { new habitats for this ubiquitous } \\
\text { species. This species also } \\
\text { colonises the margins of open } \\
\text { water in seasonally flooded } \\
\text { grasslands, presumably the } \\
\text { result of re-colonisation. }\end{array}$} & $\begin{array}{l}\text { Brinking of ditches is associated } \\
\text { with higher abundances of } \\
\text { immatures of this species. }\end{array}$ & \multirow{2}{*}{$\begin{array}{l}\text { There is no evidence that this species is a } \\
\text { nuisance biter; few adults are caught in } \\
\text { mammal-lured traps or human landing catches, } \\
\text { despite the local abundance of immatures. } \\
\text { Although capable of transmitting malaria, } \\
\text { owing to limited human biting this species } \\
\text { is unlikely to be a concern. }\end{array}$} \\
\hline & & & & $\begin{array}{l}\text { Flooding wet grassland in late } \\
\text { spring provides new habitats for this } \\
\text { species. }\end{array}$ & \\
\hline $\begin{array}{l}\text { Anopheles plumbeus } \\
\text { Stephens }\end{array}$ & ++ & Tree-holes & None & N/A & $\begin{array}{l}\text { Potential malaria vector, although not } \\
\text { previously considered to be a principal vector. }\end{array}$ \\
\hline Species & Status & Aquatic habitats & Impact of wetland creation & $\begin{array}{l}\text { Impact of wetland management } \\
\text { and possible mitigation }\end{array}$ & Nuisance or vector concern \\
\hline Aedes vexans Meigen & + & Rare; flooded grassland & Unknown, too rare & $\mathrm{N} / \mathrm{A}$ & $\begin{array}{l}\text { Potential vector of Rift Valley fever virus, however, } \\
\text { this species is currently very rare in the UK. }\end{array}$ \\
\hline \multirow[t]{2}{*}{$\begin{array}{l}\text { Aedes cinereus Meigen/ } \\
\text { Aedes geminus Peus }\end{array}$} & \multirow[t]{2}{*}{+++} & \multirow[t]{2}{*}{ Flooded fen/grassland } & \multirow{2}{*}{$\begin{array}{l}\text { Exploits a range of groundwater-fed } \\
\text { summer flooded habitats, such as } \\
\text { fens and wet grassland. How } \\
\text { quickly they colonise new flooded } \\
\text { grasslands is not yet known as } \\
\text { very few immatures have been } \\
\text { found in recently constructed wet } \\
\text { grassland in the fens despite high } \\
\text { adult densities in traps and } \\
\text { resting in grazing exclosures. It is } \\
\text { expected that colonisation will } \\
\text { take place. }\end{array}$} & $\begin{array}{l}\text { High groundwater levels in the } \\
\text { summer will dramatically } \\
\text { enhance the density of this species } \\
\text { where it occurs. This was proven } \\
\text { in the Cambridgeshire study. }\end{array}$ & \multirow{2}{*}{$\begin{array}{l}\text { The distribution of this species is patchy; however, } \\
\text { where it does occur it can be a human biting } \\
\text { nuisance. There is limited information on } \\
\text { dispersal ranges. Owing to its anthropophagy } \\
\text { and ornithophagy it has been implicated as a } \\
\text { possible bridge vector of a number of } \\
\text { arboviruses in Europe. This species will benefit from } \\
\text { expansion of reedbeds, flooded meadows and } \\
\text { seasonal summer flooding in open habitats. }\end{array}$} \\
\hline & & & & $\begin{array}{l}\text { It is possible that the timing of } \\
\text { flooding could be planned so } \\
\text { that the eggs are left high and } \\
\text { dry. Winter flooding rather than } \\
\text { spring flooding would be less } \\
\text { favourable for this species, as } \\
\text { immatures tend not to appear } \\
\text { until April. Draining of flooded } \\
\text { areas during spring would } \\
\text { significantly reduce the survival } \\
\text { of immatures. }\end{array}$ & \\
\hline
\end{tabular}


Table 1 Summary of the impact of wetland creation and management on British mosquito species, with a summary of potential for mitigation and possible nuisance/vector concern (Continued)

\begin{tabular}{|c|c|c|c|c|c|}
\hline Species & Status & Aquatic habitats & Impact of wetland creation & $\begin{array}{l}\text { Impact of wetland management } \\
\text { and possible mitigation }\end{array}$ & Nuisance or vector concern \\
\hline Aedes geniculatus Olivier & ++ & Tree-holes & None & N/A & $\begin{array}{l}\text { Not considered an important nuisance species } \\
\text { or potential disease vector }\end{array}$ \\
\hline Aedes leucomelas Meigen & + & Rare, only in a few locations & N/A & N/A & $\begin{array}{l}\text { Too rare currently to be of concern as a } \\
\text { nuisance or vector species }\end{array}$ \\
\hline Aedes caspius Pallas & +++ & $\begin{array}{l}\text { Coastal habitat; also flooded } \\
\text { fen/grassland }\end{array}$ & $\begin{array}{l}\text { Historical records of this species } \\
\text { are mainly coastal with a few } \\
\text { around London. However data } \\
\text { from the fens show that it can } \\
\text { be very common in flooded fen } \\
\text { and newly created wet grassland. } \\
\text { Furthermore, it has been } \\
\text { recorded to colonise newly } \\
\text { created freshwater (or weakly } \\
\text { saline) habitats in managed } \\
\text { re-alignment sites in estuaries. }\end{array}$ & $\begin{array}{l}\text { Managing this species inland will } \\
\text { be largely related to controlling } \\
\text { water levels. High groundwater } \\
\text { levels in summer, supplemented } \\
\text { by precipitation leading to } \\
\text { pooling and puddling in fen and } \\
\text { wet grassland will provide } \\
\text { submergence of dormant eggs. } \\
\text { Summer flooding should be } \\
\text { avoided }\end{array}$ & $\begin{array}{l}\text { Can be a nuisance species, and although not } \\
\text { considered a primary vector of Rift Valley fever } \\
\text { virus, it has been implicated as main vector in } \\
\text { Egypt. Further work to establish the role of this } \\
\text { mosquito in potential arbovirus transmission is } \\
\text { recommended, particularly considering its } \\
\text { potential for wet grassland colonisation. }\end{array}$ \\
\hline $\begin{array}{l}\text { Aedes annulipes Meigen/ } \\
\text { Aedes cantans Meigen }\end{array}$ & +++ & Wet woodland & $\begin{array}{l}\text { Not all wetland creation schemes } \\
\text { intend to create wet woodland, } \\
\text { however, where this does occur, } \\
\text { consideration needs to be given } \\
\text { to the impact of these species. }\end{array}$ & $\begin{array}{l}\text { High amounts of winter flooding, } \\
\text { and the persistence of flooded } \\
\text { woodland in spring can } \\
\text { significantly increase the densities } \\
\text { of these species. Woodland } \\
\text { ditches that are regularly slubbed } \\
\text { and re-graded are less suitable } \\
\text { for these species. However, if } \\
\text { they are allowed to dry out and } \\
\text { pools form, these habitats can } \\
\text { become suitable breeding sties. }\end{array}$ & $\begin{array}{l}\text { These species are serious nuisance biters of } \\
\text { humans, and unlike other species, they bite } \\
\text { during the day as well as at dusk. Although } \\
\text { they are known to disperse from their habitat } \\
\text { to find a host, there is no information on } \\
\text { dispersal ranges. The siting of new } \\
\text { developments near wet woodland, or the } \\
\text { creation of new wet woodland near dwellings } \\
\text { run the risk of exposing people to high biting } \\
\text { rates, especially during June-August. Both } \\
\text { species have been implicated as potential } \\
\text { arbovirus vectors based upon their host-feeding } \\
\text { habits (human and bird blood), however, } \\
\text { they are not classed as a primary vector of } \\
\text { WNV or SINV. }\end{array}$ \\
\hline Aedes communis De Geer & + & Rare, few old records & Unknown, too rare & N/A & $\begin{array}{l}\text { Too rare currently to be of concern as a } \\
\text { nuisance or vector species }\end{array}$ \\
\hline
\end{tabular}


Table 1 Summary of the impact of wetland creation and management on British mosquito species, with a summary of potential for mitigation and possible nuisance/vector concern (Continued)

\begin{tabular}{|c|c|c|c|c|c|}
\hline Species & Status & Aquatic habitats & Impact of wetland creation & $\begin{array}{l}\text { Impact of wetland management } \\
\text { and possible mitigation }\end{array}$ & Nuisance or vector concern \\
\hline Aedes detritus Haliday & +++ & Coastal, brackish; also freshwater & $\begin{array}{l}\text { Likely to be the principal mosquito } \\
\text { colonising newly created coastal } \\
\text { habitats, particularly at the spring } \\
\text { high tide mark in isolated pools } \\
\text { and in saline borrow ditches } \\
\text { capturing brackish water. }\end{array}$ & $\begin{array}{l}\text { This species exploits saline waters } \\
\text { left by spring high tides. These } \\
\text { areas generally occur at the } \\
\text { limits of existing salt-marshes, in } \\
\text { pasture or grassland subjected to } \\
\text { flooding at high tides, or in } \\
\text { vegetated ditches allowed to } \\
\text { flood during high tides. Any } \\
\text { regular tidal flushing usually } \\
\text { reduces the suitability of these } \\
\text { habitats for this species. Where } \\
\text { possible, management of spring } \\
\text { tide waters (through closure of } \\
\text { sluices) mitigate the negative } \\
\text { impact of this species. However, } \\
\text { where tides regularly leave isolated } \\
\text { pools with no drainage then } \\
\text { biocidal treatment is required. }\end{array}$ & $\begin{array}{l}\text { This species is a persistent biting nuisance and } \\
\text { responsible for several mosquito control } \\
\text { programmes in the UK. Although it is not } \\
\text { considered a principal potential vector, its } \\
\text { human and bird biting makes it a candidate } \\
\text { vector of arboviruses. However its nuisance } \\
\text { value alone makes it worthy of consideration } \\
\text { and control. }\end{array}$ \\
\hline Aedes dorsalis Meigen & + & Rare, coastal & Unknown, too localised & N/A & $\begin{array}{l}\text { Not considered to be either a nuisance or } \\
\text { vector species. Not widely distributed. }\end{array}$ \\
\hline Aedes flavescens Müller & ++ & Coastal, brackish & $\begin{array}{l}\text { Coastal marshes, although the } \\
\text { species is not common }\end{array}$ & N/A & $\begin{array}{l}\text { May cause nuisance biting, but not widespread, } \\
\text { and not considered as an important potential } \\
\text { vector. }\end{array}$ \\
\hline Aedes punctor Kirby & ++ & Acid pools, bogs & $\begin{array}{l}\text { Wet woodland sites on acid soils } \\
\text { appear to favour this species. } \\
\text { Therefore, not all wet woodland } \\
\text { would be suitable, however in } \\
\text { certain parts of England this } \\
\text { species might benefit. }\end{array}$ & $\begin{array}{l}\text { Winter/spring flooding of acid } \\
\text { habitats, particularly in bog/mire/ } \\
\text { lowland moor areas can } \\
\text { dramatically increase the numbers } \\
\text { of this species. These habitats are } \\
\text { naturally flooded by rainfall rather } \\
\text { than groundwater, so } \\
\text { management might be difficult. } \\
\text { Dwellings close to such habitats } \\
\text { will likely be impacted by wet } \\
\text { winters/springs. }\end{array}$ & $\begin{array}{l}\text { This species is not considered a principal } \\
\text { vector of arboviruses although it is a nuisance } \\
\text { species in areas adjacent to its favoured } \\
\text { breeding habitat. }\end{array}$ \\
\hline Aedes rusticus Rossi & +++ & $\begin{array}{l}\text { Wet woodland, flooded } \\
\text { rush pasture }\end{array}$ & $\begin{array}{l}\text { This species would benefit from } \\
\text { wet woodland creation and has } \\
\text { also been found in new wet } \\
\text { grassland habitats, particularly } \\
\text { those dominated by rushes. }\end{array}$ & $\begin{array}{l}\text { Spring flooding of wet grassland } \\
\text { could provide a habitat for this } \\
\text { species. Although they have not } \\
\text { been found in high numbers, } \\
\text { spring and winter flooding of } \\
\text { wet woodland would create } \\
\text { suitable habitat for this species. }\end{array}$ & $\begin{array}{l}\text { This species is not routinely considered a } \\
\text { potential vector, and although it does bite } \\
\text { humans, its pest status is not as high as Ae. } \\
\text { cantans/annulipes or Ae. detritus. However it } \\
\text { will cause nuisance biting and will benefit } \\
\text { from transient habitats subjected to winter/ } \\
\text { spring flooding. }\end{array}$ \\
\hline Aedes sticticus Meigen & + & Wet woodland, very rare & $\begin{array}{l}\text { Unknown, too rare. It may be } \\
\text { unlikely that such a rare species } \\
\text { would increase dramatically } \\
\text { with wetland creation. }\end{array}$ & $\begin{array}{l}\text { Timing of winter and spring } \\
\text { flooding of wet woodland } \\
\text { where this species occurs would } \\
\text { be a consideration. }\end{array}$ & $\begin{array}{l}\text { Nuisance and vector species elsewhere in } \\
\text { Europe, but very rare in the UK. Where this } \\
\text { species does occur, however, it can be a } \\
\text { serious pest. }\end{array}$ \\
\hline
\end{tabular}


Table 1 Summary of the impact of wetland creation and management on British mosquito species, with a summary of potential for mitigation and possible nuisance/vector concern (Continued)

\begin{tabular}{|c|c|c|c|c|c|}
\hline Species & Status & Aquatic habitats & Impact of wetland creation & $\begin{array}{l}\text { Impact of wetland management } \\
\text { and possible mitigation }\end{array}$ & Nuisance or vector concern \\
\hline $\begin{array}{l}\text { Coquillettidia richiardii } \\
\text { (Ficalbi) }\end{array}$ & +++ & $\begin{array}{l}\text { Permanent: ditches, } \\
\text { vegetated pools }\end{array}$ & $\begin{array}{l}\text { Newly created ditches with } \\
\text { emergent vegetation will provide } \\
\text { a suitable habitat for this } \\
\text { species in time. }\end{array}$ & $\begin{array}{l}\text { Owing to its enigmatic life cycle, } \\
\text { the impact of management is } \\
\text { difficult to determine. Vegetated } \\
\text { ditches and ponds will provide a } \\
\text { suitable habitat, but there is no } \\
\text { clear evidence that management } \\
\text { would be required, although this } \\
\text { species can be abundant in July } \\
\text { and cause a nuisance. }\end{array}$ & $\begin{array}{l}\text { Can be a persistent biter after dark in high summer } \\
\text { and is known to enter dwellings to bite. Not } \\
\text { considered a principal arbovirus vector, but } \\
\text { does feed on both birds and humans. }\end{array}$ \\
\hline Culex modestus Ficalbi & ++ & Localised in coastal ditches & $\begin{array}{l}\text { Not routinely found in newly } \\
\text { created wetlands, although } \\
\text { there are a few records from } \\
\text { wet grassland. }\end{array}$ & $\begin{array}{l}\text { Currently considered localised to } \\
\text { North Kent and parts of Essex } \\
\text { along the Thames estuary. Newly } \\
\text { created ditches in this area would } \\
\text { provide suitable habitat. } \\
\text { Management of this species in } \\
\text { permanent ditches might require } \\
\text { biocidal control as there are } \\
\text { currently no clear examples of } \\
\text { the impact of water or vegetation } \\
\text { management. However, } \\
\text { emergent and floating vegetation } \\
\text { appears a pre-requisite. }\end{array}$ & $\begin{array}{l}\text { Known to be a nuisance species where it occurs } \\
\text { along the Thames estuary and is also } \\
\text { considered to be a principal vector of West } \\
\text { Nile virus elsewhere in Europe. }\end{array}$ \\
\hline Culex territans Walker & + & Rare, permanent habitats & Unknown, too under-recorded & N/A & $\begin{array}{l}\text { Not considered an important nuisance species } \\
\text { or potential disease vector }\end{array}$ \\
\hline $\begin{array}{l}\text { Culex pipiens s.l. } \\
\text { Linnaeus/Culex } \\
\text { torrentium Martini }\end{array}$ & +++ & $\begin{array}{l}\text { All transient (e.g. dried } \\
\text { ditches, flooded grasslands) } \\
\text { and container habitats }\end{array}$ & $\begin{array}{l}\text { The typical biotype of } C \text {. pipiens } \\
\text { and } C \text {. torrentium colonise transient } \\
\text { habitats post-flooding, and will, } \\
\text { therefore, benefit hugely from } \\
\text { wetland creation, particularly in the } \\
\text { early pioneer stages of wetland } \\
\text { development. It is unclear which } \\
\text { species dominates and further } \\
\text { studies are required. Any nutrient } \\
\text { rich wet grassland or nutrient rich } \\
\text { permanent habitat (i.e. polluted } \\
\text { ditches, post-drought ditches, or } \\
\text { sewage treatment reedbeds) will } \\
\text { provide aquatic habitats for this } \\
\text { species. In aquatic habitats hostile } \\
\text { to predators/competitors these } \\
\text { mosquitoes will increase to large } \\
\text { densities. It is unclear whether the } \\
\text { molestus form of pipiens will be } \\
\text { affected by wetland creation. Container } \\
\text { habitats for these species are unlikely } \\
\text { to be affected by wetland creation. }\end{array}$ & $\begin{array}{l}\text { For transient aquatic habitats, } \\
\text { water-level management and } \\
\text { precipitation will be crucial. } \\
\text { Drying and re-wetting cycles of } \\
\text { transient habitats, or unnatural } \\
\text { drying of permanent habitats } \\
\text { needs to be considered in } \\
\text { relation to the rapid colonisation } \\
\text { by these species. Raising water } \\
\text { levels in wet grassland or wet } \\
\text { fen in summer could be avoided } \\
\text { to mitigate the impact of this } \\
\text { species. Furthermore, permanent } \\
\text { aquatic habitats should not be } \\
\text { allowed to dry out. Mosquitoes } \\
\text { associated with sewage treatment } \\
\text { reedbeds may require biocidal } \\
\text { control if deemed necessary, } \\
\text { although this may not be efficient } \\
\text { in nutrient-rich waters. }\end{array}$ & $\begin{array}{l}\text { Neither the typical biotype of } C \text {. pipiens nor } \\
C x \text {. torrentium are nuisance species as they almost } \\
\text { exclusively feed on birds. They are both } \\
\text { considered important enzootic vectors of WNV } \\
\text { and Sindbis virus respectively. In the event of } \\
\text { such an outbreak, management of their } \\
\text { populations will be crucial in managing the } \\
\text { enzootic transmission of the viruses. The } \\
\text { molestus form is also a potential WNV vector, } \\
\text { but is unlikely to be affected by wetland } \\
\text { management given its predilection for } \\
\text { underground and cloistered container habitats. }\end{array}$ \\
\hline
\end{tabular}


Table 1 Summary of the impact of wetland creation and management on British mosquito species, with a summary of potential for mitigation and possible nuisance/vector concern (Continued)

\begin{tabular}{|c|c|c|c|c|c|}
\hline Species & Status & Aquatic habitats & Impact of wetland creation & $\begin{array}{l}\text { Impact of wetland management } \\
\text { and possible mitigation }\end{array}$ & Nuisance or vector concern \\
\hline $\begin{array}{l}\text { Culiseta longiareolata } \\
\text { (Macquart) }\end{array}$ & + & Rare, too few records & Unknown, too rare & N/A & N/A \\
\hline $\begin{array}{l}\text { Culiseta fumipennis } \\
\text { (Stephens) }\end{array}$ & + & Rare, too few records & Unknown, too rare & N/A & $\begin{array}{l}\text { Not considered an important nuisance species } \\
\text { or potential disease vector }\end{array}$ \\
\hline Culiseta litorea (Shute) & + & Coastal, rare, too few records & Unknown, too rare & N/A & $\begin{array}{l}\text { Not considered an important nuisance species } \\
\text { or potential disease vector }\end{array}$ \\
\hline $\begin{array}{l}\text { Culiseta morsitans } \\
\text { (Theobald) }\end{array}$ & ++ & Permanent waters & $\begin{array}{l}\text { It is expected that this species } \\
\text { would benefit from the } \\
\text { development of permanent } \\
\text { waters, although they have } \\
\text { been caught in such low } \\
\text { numbers, there is insufficient } \\
\text { data to determine the full impact } \\
\text { of wetland creation. }\end{array}$ & $\begin{array}{l}\text { There is little available information } \\
\text { on the impact of wetland } \\
\text { management, although vegetated } \\
\text { ditches and reedbed that are } \\
\text { subjected to drying and remain } \\
\text { wet thereafter do provide a } \\
\text { habitat for this species. It may } \\
\text { not be necessary to control this } \\
\text { species, but if required, certainly } \\
\text { water level management will } \\
\text { be crucial. }\end{array}$ & $\begin{array}{l}\text { Not considered an important nuisance species } \\
\text { owing to its largely ornithophagic tendencies. } \\
\text { However, it is a potential enzootic disease } \\
\text { vector in Europe and they have been reported } \\
\text { to bite humans. However, they are heavily } \\
\text { under-recorded in adult mosquito sampling. }\end{array}$ \\
\hline $\begin{array}{l}\text { Culiseta alaskaensis } \\
\text { (Ludlow) }\end{array}$ & + & $\begin{array}{l}\text { Northern species: rare, too } \\
\text { few records }\end{array}$ & Unknown, too rare & N/A & $\begin{array}{l}\text { Not considered an important nuisance species } \\
\text { or potential disease vector }\end{array}$ \\
\hline $\begin{array}{l}\text { Culiseta annulata } \\
\text { (Schrank) }\end{array}$ & +++ & $\begin{array}{l}\text { Exploits a range of permanent, } \\
\text { transient and container habitats }\end{array}$ & $\begin{array}{l}\text { Will benefit from a range of } \\
\text { wetland creation schemes, such } \\
\text { as ditches subjected to drying, } \\
\text { wet woodland with water } \\
\text { persisting through to late summer, } \\
\text { nutrient-rich wet grassland } \\
\text { in late summer and drying } \\
\text { nutrient rich reedbeds. }\end{array}$ & $\begin{array}{l}\text { Wet woodland that remains wet } \\
\text { throughout the year will provide } \\
\text { a suitable breeding habitat for } \\
\text { this species, which would also } \\
\text { dominate in nutrient rich wet } \\
\text { grassland. If this species is a } \\
\text { problem then late summer } \\
\text { flooding will be significant. } \\
\text { Ditches allowed to dry and } \\
\text { re-wet will also provide a suitable } \\
\text { habitat. This species will also } \\
\text { colonise polluted container } \\
\text { habitats in urban areas, where } \\
\text { they may be more of an issue. }\end{array}$ & $\begin{array}{l}\text { This species is one of the most common } \\
\text { nuisance species in the UK, although not } \\
\text { necessarily biting in as high numbers as other } \\
\text { species. It is large and owing to its colouration } \\
\text { is often confused with some much smaller } \\
\text { invasive species. Although not a principal } \\
\text { arbovirus vector, its ability to feed on humans } \\
\text { and birds (in urban areas) makes it a } \\
\text { candidate vector. }\end{array}$ \\
\hline $\begin{array}{l}\text { Culiseta subochrea } \\
\text { (Edwards) }\end{array}$ & + & $\begin{array}{l}\text { Similar to Cs. annulata, likely } \\
\text { under-recorded. Ecology not } \\
\text { considered distinct from } \\
\text { Cs. annulata }\end{array}$ & N/A & N/A & $\begin{array}{l}\text { Not considered an important nuisance species } \\
\text { or potential disease vector }\end{array}$ \\
\hline $\begin{array}{l}\text { Orthopodomyia } \\
\text { pulcripalpis Rondani }\end{array}$ & + & Tree holes, rare & N/A & N/A & $\begin{array}{l}\text { Owing to its ornithophagic tendencies, this } \\
\text { species is not considered an important } \\
\text { nuisance species or a potential disease vector }\end{array}$ \\
\hline
\end{tabular}

Key references: [5,29,32,34-46].

Status: +++ widespread, ++ more localised but locally abundant, + very focal or rare. 
negligible. However, three of the eight sites support populations of two nuisance and potential arboviral vector species, Aedes detritus and Aedes caspius. These new breeding sites resulted from specific design aspects of the new sea wall; (a) an additional bank of ballast to mitigate wave action provided a linear habitat that supported significant numbers of mosquitoes, (b) during construction of the sea wall, saline borrow ditches were excavated and these now fill with brackish waters at spring high tides, and tidal waters collect on vegetated banks in culverts with minimal tidal flushing, and (c) isolated pools have been created through silt accretion or expansion of flooded zones to neighbouring pasture. Specific issues appear to be related to sites on a case by case basis, but in each case aquatic habitat that supports nuisance biting mosquito species has been created that, in some cases, reduced tourist visits and/or impacted on the local community.

There is likely to be some nuisance biting associated with sites that support flooded habitats that are not regularly flushed by the tide, and a management plan may be needed to deal with these sites if they continue to promote nuisance biting by Ae. detritus and Ae. caspius. Similar controls would also be needed if, in the future, these species become implicated in disease transmission. Ideally, consideration should be given to the creation of potential aquatic mosquito habitats prior to any MRA construction, as part of the Environmental Impact Assessment, with further consideration as to how such habitats could be minimised. Ongoing monitoring of such sites for mosquitoes should be instituted as part of regular faunal and floral monitoring and public health risk assessment for each site. It is possible that using field generated evidence-based findings, targeted mosquito management for specific nuisance species could be put in place that involved small changes to flooding regimes or sluice management. For example at one site in Essex, closing of sluices to prevent over-flooding of ditches at spring high tides would minimise vegetation flooding and thus mitigate the problems encountered with Ae. detritus. However, the management of each site must be considered on a case-by-case basis.

Urban wetland creation - mitigation for urban development The drivers for developing new wetlands in urban areas are manifold [11]; e.g., ecological mitigation to offset loss of wetland habitat for European protected species, local urban flood-risk management, particularly where housing developments are constructed in areas prone to flooding, and improvement in local public access to natural areas has led to the creation of extended urban green and blue space. In some cases there is a drive to provide sustainable urban drainage, which may involve harnessing the ability of wetlands to sanitise sewage to minimise local environmental pollution. Urban green and blue space is increasingly being promoted to mitigate the urban heat island effect.

There is a dearth, however, of field-based evidence on the impact of urban wetland creation schemes on mosquito populations in Europe. Studies in England have begun to address this [34]. New wetlands created in urban and peri-urban locations in England generally take a similar form, usually directed by the requirements of protected wildlife species and government legislation. In the UK, permanent water bodies in the form of ponds or ditches are created for Great Crested Newts and Water Voles. Reedbeds and open water areas are created for migrant warblers and wildfowl. Transient winter-flooded scrapes are created for wading birds such as Lapwing. In addition, many sites also have a constructed reed-bed, separated hydrologically from the rest of the wetland, which is used to treat sewage from the local community, particularly during flash-flood events to reduce environmental contamination.

Studies on the impact of the creation of such habitats on local mosquito populations in England are revealing. These aquatic habitats are hugely responsive to changes in the water table caused by precipitation. Colonisation by mosquitoes of permanent habitats (such as open water, marginal reed areas and ditches) appears to be extremely slow, particularly during the first two years before marginal, floating and submerged vegetation has developed, when these sites can become suitable for anophelines. Furthermore, fluctuations in water depths of these groundwater-fed permanent habitats can, during the early phases of reed planting, lead to drying out and/ or flooding of planted emergent vegetation, such as reeds, which further delays mosquito colonisation. In contrast however, transient aquatic habitats (subjected to repeated wetting and drying), particularly those with a vegetated substrate, are quickly exploited by mosquitoes, and densities of mosquitoes are further enhanced by periods of drying and re-wetting that exclude all competitors and predators. In the UK, the dominant mosquito species in this ephemeral habitat are Culex pipiens s.1./ Culex torrentium- which are known elsewhere in Europe for acting as an important enzootic (transmission between birds) vector of West Nile virus and Sindbis virus. Densities of immature Culex were reported to be 33 times higher in transient versus permanent habitats, and 41 times higher in vegetated compared with unvegetated habitats [34].

However, the situation is slightly different in reedbeds created for sewage treatment. These are designed to remove phosphorus from sewage effluent, with the resultant water entering the river system. These tend to be self-contained systems, separate from the rest of the urban wetland. Crucially they include an unvegetated 
stilling basin that holds the sewage prior to passage through the reedbed. Studies in England found that these treatment reedbeds contributed significantly to the local density of mosquitoes. This was particularly the case following an influx of sewage in the stilling basin. The incoming sewage acts as a productive food source for Culex pipiens, with immature mosquito densities reaching several thousand per litre of surface water. Overall, mean densities of immature Culex were reported to be 80 times higher in the stilling basin compared to all other aquatic habitats created in the new urban wetland, with larval densities 150 times higher in the sewage filled stilling basin compared to the rest of the sewage treatment reedbed [34].

In the event of an outbreak of West Nile virus the numbers of mosquitoes exploiting these stilling basins needs to be considered. Several months following a sewage input event, the high nutrient levels, coupled with high summer temperatures, can create blooms of bluegreen algae, which also supports immature mosquitoes, but to a much lesser degree [34]. Throughout the rest of the vegetated sewage treatment reedbed mosquito numbers tend to be low (including Anopheles claviger, An. maculipennis s.l., Culex pipiens and Culiseta annulata), as there is an assemblage of predators. However, such habitats should not be allowed to dry out as this would negatively impact populations of natural predators.

Currently no consideration is given to the impact of urban wetland creation on mosquito numbers or future vector-borne disease risk in the UK, and yet this should be a primary consideration of all future wetland construction applications and included in the environmental impact assessment. Groundwater management and effluent inflow will contribute to the majority of culicine populations and appropriate targeted management using biocidal control should be used to manage these species.

\section{Freshwater wetland management and expansion including arable reversion}

The Wetland Vision for England [9] outlines exciting plans to restore existing wetlands and create new wetlands from areas currently under agriculture. This is an attempt to provide an increased resource for biodiversity, assist with alleviating inland flooding and re-connect extant nature reserves to ensure that wildlife species are able to adapt to the impact of climate change. There has long been a recognition that extant highly-biodiverse wetland habitats require ongoing management to maintain a range of wetland communities with various seral stages, including tall fen, fen meadow, rush pasture, swamp, open water, permanent and temporary ditches, and wet woodland. An unmanaged wetland eventually becomes woodland. These different wetland types support a varied range of mosquito species. The impact of seasonal rainfall and/ or management of water levels can impact significantly on the survival and abundance of these species. Often the impact varies between sites, so that an assessment of wetland management and extreme weather events on mosquito numbers is only possible on a case-by-case basis, although there are some general principles that will now be discussed.

In addition to management of extant wetlands, there is also recognition of how these habitats have become fragmented across a landscape through the expansion of agriculture. One of the goals, therefore, for climate change adaptation is to de-fragment these wetlands to ensure that wildlife species can adapt to changes in climate and have many more staging posts to ensure their survival. One of the key components of Wetland Vision projects, such as the Great Fen project and the Wicken Fen vision (both in Cambridgeshire, UK) is to expand existing wetlands through arable reversion. This involves purchasing neighbouring arable land (often land that had previously existed as wetland prior to drainage) and re-seed and re-wet it; often managing it as wet grassland with grazing animals (an important food source for mosquitoes).

It is important to consider the variation in general lifehistories of mosquito species and how these relate to wetland types $[2,29,35,36]$. Some mosquito species exploit only permanent wetlands such as ponds and ditches. Larger lakes tend to be inimical for mosquitoes as they are subject to surface movements that prevent immature mosquito survival. Furthermore, certain wetland types (such as reedbeds) with extensive drawdown zones (area at the edge of a body of water that is frequently exposed to the air due to changes in water levels) do not tend to support mosquitoes. A vegetated substrate or the presence of floating or emergent vegetation is generally required to support mosquitoes in permanent wetlands. Another group of mosquito species thrive in temporary water that is subjected to seasonal flooding and drying. Mosquitoes of wet woodland tend to exploit winter flooded habitats, with immature development occurring during late winter and early spring prior to summer drying. Mosquitoes of wet grassland remain dormant during winter as eggs, awaiting summer floods, upon which immatures develop in late spring for a summer emergence of adults. Wetlands that routinely dry and re-wet tend to have the associated groups of invertebrates adapted to this habitat which are also competitors and predators of mosquitoes, however, the erratic nature of such ephemeral habitats leads to higher than average mosquito densities. For healthy permanent wetlands, however, mosquito numbers are maintained by the food web, owing to the multitude of mosquito predator species. One of the main challenges, however, is associated with extreme events, such as drought, 
which results in the relatively rare drying of permanent wetlands, followed by a re-wetting event and a subsequent dramatic increase in mosquito numbers in the absence of competitors and predators [3].

If we now relate this variability in habitat conditions that are suitable for mosquito breeding, to wetland management we can see that maintaining permanent wetlands throughout the year is crucial to minimise the effect of permanent wetlands as a source of nuisance mosquitoes. Studies of the Great Fen project [29] have shown that permanent wetlands maintained low densities of anopheline mosquitoes (e.g. An. maculipennis s.l., An claviger). However, if ditches dried during a drought event, upon re-wetting, large numbers of culicines colonised (e.g. Cx. pipiens, Cs. annulata) the area. Anophelines accounted for $98 \%$ of all mosquitoes collected from the ditches that remained wet, however, ditches subjected to drying were dominated by culicines (93\%). The process of slubbing (digging out ditches) can prevent this and should be promoted. The vegetation surrounding ditches is also managed (a process known as brinking), and seasonal brinking can affect the densities of mosquito immatures by raising water temperatures, which favours some species (particularly An. maculipennis s.l.). Significantly more immature anophelines were shown to occur in ditches that had been subjected to cutting of marginal vegetation in late spring [29].

With respect to temporary water bodies, the timing and intensity of flooding (through precipitation or raising water levels) can affect a range of mosquito species. Prolonged winter and spring flooding in wet woodland habitats can prolong the period in which immature mosquitoes can complete development and thus increase the density of nuisance woodland mosquitoes.

Summer precipitation favours high density populations of floodwater mosquito species, particularly in wet grassland habitats where the effects can be profound due to there being two phases of development in these species [29]. Firstly the mosquitoes that deposited eggs the previous year in areas prone to flooding emerge first, usually in synchrony. This can lead to large numbers of nuisance and vector species (e.g. Ae. caspius, Ae. vexans, Ae. sticticus). This is usually followed by colonisation of a different set of species (e.g. Cx. pipiens, Cs. annulata) that oviposit on open water and thrive in drying nutrient rich waters provided there is a vegetated substrate or marginal vegetation. Late spring rainfall appears to be crucial in determining the retention of water levels in these habitats. An already high water table, exacerbated by summer rains, can be ideal for high densities of floodwater mosquitoes. A flooded river in a river valley has a similar effect.

Late summer rains can also be retained by wetland managers in wet grassland habitats through a series of sluices, thus retaining water on the grasslands through winter to promote winter visiting wildfowl. The timing of the commencement of this flooding is crucial. Flooding as late as September and October can still promote immature mosquito development, particularly if unseasonably high temperatures promote rapid development through to emergence of nuisance adults [29]. These are important considerations during arable reversion to wet grassland. A very wet late spring and summer, or a wetland subjected to management of summer water levels will have a profound effect in supporting nuisance and vector mosquitoes. Wetlands that either stay very wet, or remain very dry will likely have a lower impact. There appears to be a depth threshold in these wet grasslands above which mosquitoes cease to exist [29]. Therefore, it may be possible that during an outbreak situation, raising water levels above specific depth thresholds will make the habitat inimical for mosquito development. However, natural or unnatural re-wetting of wet grassland during summer will contribute to large numbers of nuisance and potential vector species. These findings have important implications for understanding the impact of extreme weather events such as drought and flooding. However, it is important to consider that through wetland management, aquatic habitats are subjected to flooding and drought on a regular basis, often independent of weather conditions.

In summary, different types of wetland support a range of different mosquito species, depending upon the range of wetland types and the size and age of the wetland. Management of water levels at specific times of year can have a profound effect on mosquito densities. Understanding the impact of seasonal rains and water level management needs to be considered on a case-by-case basis using the generic principles outlined above. Wetlands close to dwellings may even need a mosquito management plan. This will be increasingly important during disease outbreak situations.

\section{Review and conclusion}

It is vital that wetland creation, expansion and management plans take into account the effects that wetland management might have on mosquito populations, nuisance-biting levels, and public and veterinary health. It is also necessary that such biodiversity initiatives have the knowledge and tools to enable them to assess and manage this impact as their work proceeds. It is crucial that environmentally-friendly mitigation strategies and wetland site locations are chosen with mosquito life histories in mind in order to minimise or avoid potentially deleterious effects. The environment sector recognises that there is a need for an evidence-base to inform future wetland creation and management initiatives and public health entomologists in the UK are now working 
to develop this evidence base and appropriate guidance with wetland experts. Applied correctly and, where possible, exploiting biodiversity and wetland management could become key tools in keeping mosquito populations at desirable levels. However, this can only be achieved if environmental impact assessments for new wetlands consider mosquitoes in their health chapter, and that wetland management plans develop a contingency for mosquito management (through wetland management strategies rather than only biocide usage) in the event of an outbreak. There will be no time to devise such plans in the face of an outbreak, so prior planning is highly recommended. The fact that wetlands do produce aquatic habitats for mosquitoes should be accepted, but it should also be recognised that evidenced-based management strategies targeted at key mosquito species will be crucial in managing disease outbreaks (or nuisance mosquito problems). Furthermore, a combined effort from environmental and public/veterinary health sectors is required to ensure that in the event of a mosquito-borne disease outbreak biocidal and environmental control of mosquitoes is appropriate and targeted to ensure maximum efficacy at minimal cost. A summary of the possible impact of wetland creation, wetland management and possible mitigation and perceived nuisance or vector concerns are given for all UK species in Table 1. It should be noted that much more research is required to refine these recommendations and to understand further the impact of wetlands on mosquitoes. There is also a requirement to better understand the biological and ecological complexities of mosquito species complexes through better molecular identification. In conclusion, developing this evidencebase ahead of a disease outbreak is currently a primary objective of public health and environmental agencies.

\section{Competing interests}

The authors declare that they have no competing interests.

\section{Authors' contributions}

JMM jointly conceived the manuscript, led the preparation of the manuscript and approves the manuscript and can account for its content. AGCV jointly conceived the manuscript, contributed to the scientific content, and has approved the manuscript and can account for its content.

\footnotetext{
Acknowledgements

This work was part funded by the EU PHASE project. JMM's time was part-funded by the National Institute for Health Research Health Protection Research Unit (NIHR HPRU) in Emerging and Zoonotic Infections at the University of Liverpool in partnership with Public Health England (PHE) and the Liverpool School of Tropical Medicine, and partly funded by the NIHR HPRU in Environmental Change and Health at the London School of Hygiene and Tropical Medicine in partnership with PHE, and in collaboration with the University of Exeter, University College London, and the Met Office. The views expressed are those of the authors and not necessarily those of the National Health Service, the NIHR, the Department of Health or Public Health England.
}

Received: 2 January 2015 Accepted: 18 February 2015

Published online: 03 March 2015

\section{References}

1. Medlock JM, Snow KR. Natural predators and parasites of British mosquitoes - a review. Eur Mosq Bull. 2008;25:1-11.

2. Medlock JM, Vaux AGC. Assessing the possible implications of wetland expansion and management on mosquitoes in Britain. Eur Mosq Bull. 2011:29:38-65.

3. Brown L, Medlock JM, Murray V. Impact of drought on vector-borne disease. How do we manage the risk? Public Health. 2014;128(1):29-37.

4. Stanke C, Kerac M, Prudhomme C, Medlock JM, Murray V. Health effects of drought: a systemic review of the evidence. PLoS Curr Disasters. 2013;5:5.

5. Medlock JM, Vaux AGC. Colonization of UK coastal re-alignment sites by mosquitoes: implications for design, management and public health. J Vect Ecol. 2013;38:53-62.

6. Gad AM, Farid HA, Ramzy RR, Riad MB, Presley SM, Cope SE, et al. Host feeding of mosquitoes (Diptera: Culicidae) associated with the recurrence of Rift Valley fever in Egypt. J Med Entomol. 1999;36(6):709-14.

7. Bisanzio D, Giacobini M, Bertolotti L, Mosca A, Balbo L, Kitron U, et al. Spatio-temporal patterns of distribution of West Nile virus vectors in eastern Piedmont Region, Italy. Parasit Vectors. 2011;4:230.

8. Leggett DJ, Cooper N, Harvey R. Coastal and estuarine managed realignment-design issues. London: CIRIA; 2004. p. 46.

9. Hume C. Wetland Vision Technical Document: overview and reporting of project philosophy and technical approach. The Wetland Vision Partnership; 2008.

10. Hemingway KL, NC Cutts, Pérez-Dominguez R. Managed Realignment in the Humber Estuary, UK. Institute of Estuarine and Coastal Studies (IECS), University of Hull, UK. 2008 Report produced as part of the European Interreg IIIB HARBASINS project.

11. HMSO. Planning Policy Statement 9: Biodiversity and Geological Conservation. 2005. Available at: http://www.planningportal.gov.uk/ planning/planningpolicyandlegislation/previousenglishpolicy/ppgpps/pps9.

12. Bowley A. The Great Fen - a waterland for the future. Brit Wld. 2007;18(6):415-23.

13. National Trust. Wicken Fen Vision. 2009. http://www.nationaltrust.org.uk.

14. Rey JR, Walton WE, Wolfe RJ, Connelly CR, O'Connell SM, Berg J, et al. North American wetlands and mosquito control. Int J Env Res Pub Health. 2012;9(12):4537-605.

15. Lindsay SW, Willis SG. Predicting future areas suitable for vivax malaria in the United Kingdom. Report to the Foresight project 'Infectious Diseases: preparing for the future' 2006. Available online: www.foresight.gov.uk.

16. ECDC [European Centre for Disease Prevention \& Control]. West Nile virus risk assessment tool. Stockholm: ECDC; 2013. Available at: http://www.ecdc. europa.eu/en/healthtopics/west_nile_fever/risk-assessment-tool/Pages/riskassessment-tool.aspx

17. ECDC [European Centre for Disease Prevention \& Control]. West Nile virus case data 2012 and 2013. Stockholm: ECDC; 2015. Available at: http://ecdc. europa.eu/en/healthtopics/west_nile_fever/West-Nile-fever-maps/Pages/ 2012-table.aspx.

18. ECDC [European Centre for Disease Prevention \& Control]. RAPID RISK ASSESSMENT Update on autochthonous Plasmodium vivax malaria in Greece. Stockholm: ECDC; 2011. Available at: http://www.ecdc.europa.eu/en/ publications/Publications/131003_TER_Malaria_Greece_Risk_Assessment.pdf.

19. Stiasny K, Aberle S, Heinz F. Retrospective identification of human cases of West Nile virus infection in Austria (2009 to 2010) by serological differentiation from Usutu and other flavivirus infections. Eurosurv. 2013;18(43):20614

20. Chevalier V, Pépin M, Plée L, Lancelot R. Rift valley fever - a threat for Europe? Eurosurv. 2010;15(10):19506.

21. Ahlm C, Eliasson M, Vapalahti O, Evander M. Seroprevalence of Sindbis virus and associated risk factors in northern Sweden. Epidemiol Inf. 2014;142(7):1559-63.

22. Hubálek Z, Rudolf I, Bakonyi T, Kazdová K, Halouzka J, Sebesta O, et al. Mosquito (Diptera: Culicidae) surveillance for arboviruses in an area endemic for West Nile (Lineage Rabensburg) and Tahyna viruses in Central Europe. J Med Entomol. 2010;47(3):466-72.

23. Medlock JM, Hansford KM, Schaffner F, Versteirt V, Hendrickx G, Zeller $\mathrm{H}$, et al. A review of the invasive mosquitoes in Europe: ecology, public health risks, and control options. Vector Borne Zoonot Dis. 2012;12(6):435-47

24. Schaffner F, Medlock JM, Van Bortel W. Public health significance of invasive mosquitoes in Europe. Clin Microbiol Infect. 2013;19(8):685-92. 
25. Becker N. Microbial control of mosquitoes: management of the upper rhine mosquito population as a model programme. Parasitol Today. 1997;13(12):485-7

26. Schäfer ML, Lundström JO, Petersson E. Comparison of mosquito (Diptera: Culicidae) populations by wetland type and year in the lower river Dalälven region, Central Sweden. J Vect Ecol. 2008;33(1):150-7.

27. Schäfer ML, Lundström JO. The present distribution and predicted geographic expansion of the floodwater mosquito Aedes sticticus in Sweden. J Vect Ecol. 2009;34(1):141-7.

28. Ponçon N, Toty C, L'ambert G, le Goff G, Brengues C, Schaffner F, et al. Population dynamics of pest mosquitoes and potential malaria and West Nile virus vectors in relation to climatic factors and human activities in the Camargue, France. Med Vet Entomol. 2007;21(4):350-7.

29. Medlock JM, Vaux AGC. Seasonal dynamics and habitat specificity of mosquitoes in an English wetland: Implications for UK wetland management and expansion. J Vect Ecol. 2015; in press.

30. Linton Y-M, Lee AS, Curtis C. Discovery of a third member of the Maculipennis group in SW England. Eur Mos Bull. 2005;19:5-9.

31. Medlock JM, Vaux AGC. Aedes (Aedes) geminus Peus (Diptera, Culicidae) - an addition to the British mosquito fauna. Dipterists Digest. 2009;16:147-50.

32. Golding N, Nunn MA, Medlock JM, Purse BV, Vaux AGC, Schafer SM. West Nile virus vector Culex modestus established in southern England. Parasites Vectors. 2012;5:32. doi:10.1186/1756-3305-5-32.

33. Medlock JM, Vaux AGC, Gibson G, Hawkes FM, Cheke RA. Potential vector for West Nile virus prevalent in Kent. Vet Record. 2014;175:284-5.

34. Medlock JM, Vaux AGC. Colonization of a newly constructed urban wetland by mosquitoes in England: implications for nuisance and vector species. J Vect Ecol. 2014:39(2):249-60.

35. Marshall JF. The British mosquitoes. London: British Museum (Natura History); 1938.

36. Cranston PS, Ramsdale CD, Snow KR, White GB. Adults, larvae and pupae of British mosquitoes (Culicidae). Scientific Publication 1987, no. 48, pp. 1-152. Freshwater Biological Association, Ambleside, Cumbria.

37. Service MW. Observations on feeding and oviposition in some British mosquitoes. Entomol Exp App. 1968;11:286-90.

38. Service MW. Observations on the ecology of some British mosquitoes. Bull Entomol Res. 1969;59:161-94.

39. Service MW. Feeding behaviour and host preferences of British mosquitoes. Bull Entomol Res. 1971;60:653-61.

40. Service MW. The biology of Anopheles claviger (Mg.) (Diptera, Culicidae) in southern England. Bull Entomol Res. 1973;63:347-59.

41. Service MW. The biology of Culiseta morsitans and Culiseta litorea in England. Bull Entomol Res. 1994;84:97-104.

42. Snow KR. Mosquitoes. Naturalists' Handbooks Series. London:Richmond Publishers; 1990

43. Medlock JM, Snow KR, Leach S. Potential transmission of West Nile virus in the British Isles: an ecological review of candidate mosquito bridge vectors. Med Vet Entomol. 2005;19:2-21

44. Medlock JM, Snow KR, Leach S. Possible ecology and epidemiology of medically important mosquito-borne arboviruses in Great Britain. Epidemiol Inf. 2007;135:466-82

45. Snow KR, Medlock JM. The mosquitoes of Epping Forest, Essex, UK. Eur Mosq Bull. 2008;26:9-17.

46. Medlock JM, Vaux AGC. Distribution of West Nile virus vector, Culex modestus in England. Vet Rec 2012, September 15. 278. doi:10.1136/vr.e6123

\section{Submit your next manuscript to BioMed Central and take full advantage of:}

- Convenient online submission

- Thorough peer review

- No space constraints or color figure charges

- Immediate publication on acceptance

- Inclusion in PubMed, CAS, Scopus and Google Scholar

- Research which is freely available for redistribution 